\title{
Pregnancy associated arbovirus infections
}

\author{
Fauzia Nausheen $^{1 *}$, Shayan S Bashir ${ }^{2}$ and Dhammika N Atapattu ${ }^{1,3}$ \\ ${ }^{1}$ Department of Medical Education, California University of Science and Medicine, Colton, California, USA \\ ${ }^{2}$ Kennedy Medical Clinic, Brampton, Ontario, Canada \\ ${ }^{3}$ Department of Pathobiological Sciences, University of Wisconsin - Madison, Wisconsin, USA
}

\begin{abstract} arthralgia, conjunctivitis, paralysis, meningoencephalitis and hemorrhage.

\section{Introduction}

Arboviruses are the group of the viruses transmitted by arthropod vectors [1]. As many as 135 arboviruses are responsible for human infections. Historically, the connection between invertebrate vectors such as mosquitoes and human disease was first proposed by a Cuban doctor Carlos Finlay (1881) [2] and was later verified by Walter Reed (1901) [3].The transmission of viral infections by the Aedes mosquitoes, was confirmed (1906) after an epidemic of Dengue fever occurred in $18^{\text {th }}$ and $19^{\text {th }}$ century $[4,5]$.
\end{abstract}

Arboviruses are transmitted through bites of arthropod vectors. The virus, after replicating at the primary site, enters blood of the host (primary viremia), then it infiltrates reticuloendothelial system (secondary viremia), which is responsible for the symptoms. The common arboviruses associated with fetal abnormalities and neonatal infections are: Zika, Dengue, Japanese encephalitis (JEV), Yellow fever (YFV), West Nile virus (WNV) and Chikungunya.

The pathogenesis of arboviruses diseases is related to immune activation, production of inflammatory mediators and direct cell cytotoxicity. The laboratory tests are based on the detection of specific viral antigens, viral genomes and antibodies. Pregnancy associated viral infections produce symptoms ranging from fever, rash,

Vaccine preventable arboviruses include JEV, YFV and Dengue Virus (vaccine to be commercially available soon). An integrated approach involving health education, vector control, vaccine prophylaxis, good obstetric practices and advanced diagnostic technologies can reduce the global burden of disease.

Arboviruses go through a life cycle that completes within a vertebrate host. The bite of an arthropod vector results in transmission of the microorganism [6,7]. The most common arthropod vectors are mosquitoes and ticks. Inside the host, the virus replicates at the primary site of infection and then enters the blood of host causing a primary viremia [8]. From the blood, these viruses enter the cells of the reticuloendothelial system where they further replicate, resulting in a higher viral load called secondary viremia [9]. These viruses are then transmitted from the host blood to other susceptible hosts via an infected vector that feeds on the infected blood of the host (Figure 1). The host can also act as the "dead end host' if the amplification process resulting in viremia does not occur in the primary host. These are usually the intermediate hosts that does allow transmission of the virus to definite hosts as compared to an amplifying host in which pathogen amplifies and vector can get infected and transmit the virus [10].

\section{Objective}

The objective of this review is to assist health care workers with information regarding some of the common arboviruses: Dengue, Zika, West Nile, Yellow fever and Chikungunya.

\section{Dengue virus \\ Epidemiology}

The first report of dengue-like disease comes from the Chinese medical encyclopedia dating back to 610 - 992 AD [11]. Dengue virus produces illnesses in about 96 million people annually throughout the world [12]. They are the members of the family: flaviviridae, genus; Flavivirus [5], and has at least four distinct antigenically related serotypes. The cycle starts with a human bite of female Aedes aegypti mosquito [13]. These infected Aedes mosquitos transmit dengue virus via their saliva. The incubation period of the disease is usually 4-6 days. Viremia develops during the late incubation period and may persists 3-8 days or until the fever subsides $[14,15]$.

During the period of viremia, the mosquito may acquire infection from an infected human takes 8-10 days before it becomes capable of transmitting to another susceptible individual. The virus stays in the mosquito for its life span and mosquito acts as a carrier to transmit infections to several individuals. Epidemics of dengue virus infection usually occur with a single strain but if multiple strains are involved, it is referred to as an hyperendemic [16]. The vector density, their movement and the availability of susceptible individuals enhances the dengue virus transmission. Aedes aegypti and dengue viruses

${ }^{\star}$ Correspondence to: FFauzia Nausheen, Department of Medical Education California University of Science and Medicine, 217 E Club Center Dr Suite A, San Bernardino, CA 92408, California, USA, Tel: 586-339-5341, E-mail: Nausheenf@calmedu.org

Key words: arboviruses, mosquitoes, congenital abnormalities, abortions, fever

Received: July 17, 2018; Accepted: August 07, 2018; Published: August 10, 2018 

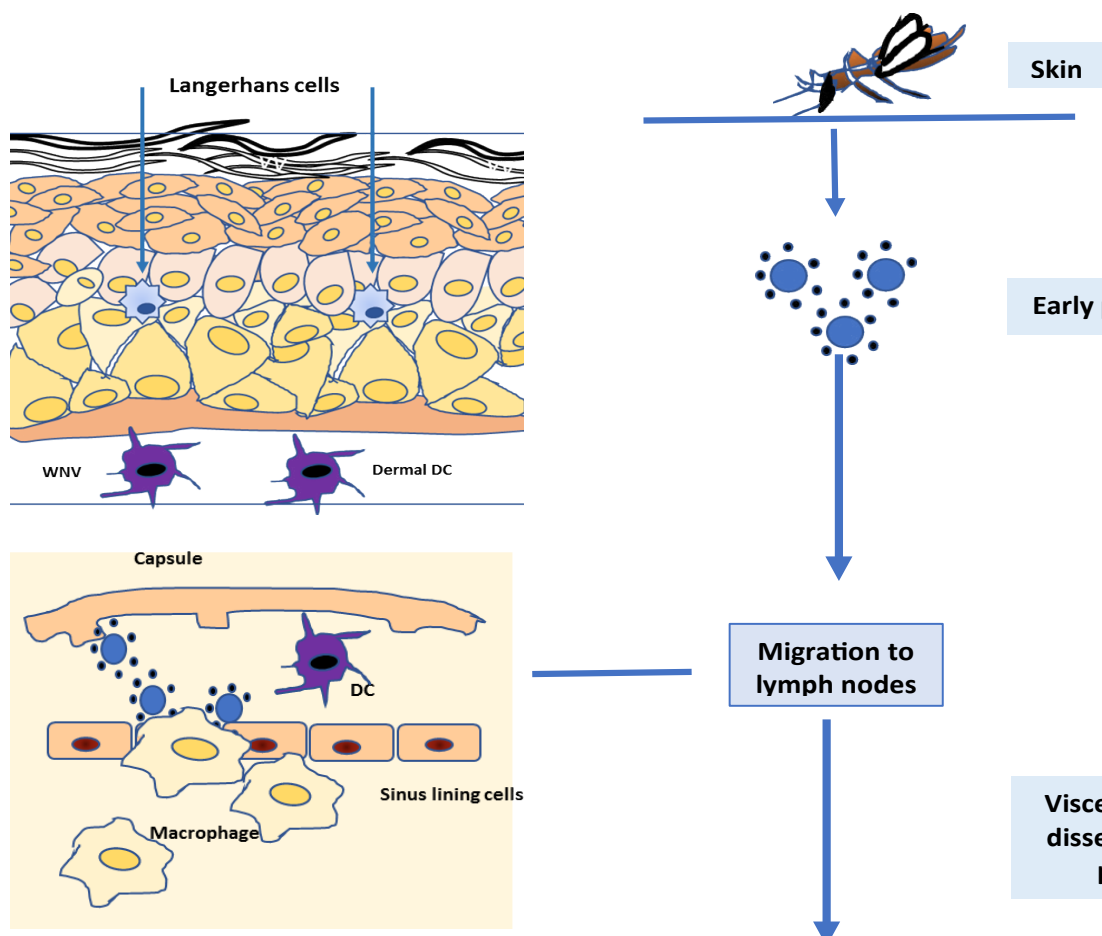

Early phase
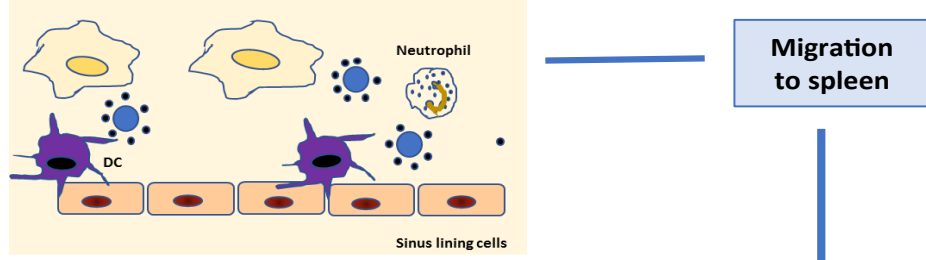

Migration to

lymph nodes

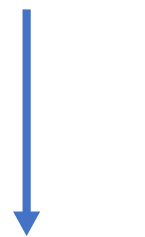
Visceral-organ
dissemination
phase
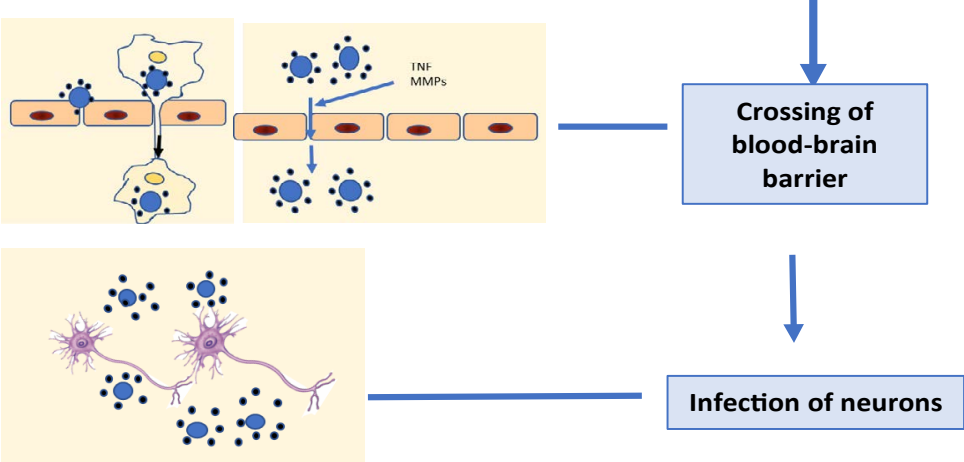

CNS phase

Figure 1. A schematic demonstrating the key stages of Arbovirus pathogenesis from the point of virus entry in the skin to the infection of neurons or other susceptible cells of the body

are endemic globally except for temperate Europe. Epidemic dengue hemorrhagic fever occurs predominantly in Asia and the Americas [17].

\section{Pathogenesis}

The pathogenesis depends on the genetic predisposition and immunity of host as well as viral virulence. In the past 50 years the incidence of dengue has increased 30 folds, primarily in the Asia and the Americas.

Dengue can result in severe disease if the patient is exposed to a different serotype during previous infections. Because the antibodies generated from the first infection do not neutralize but increase the uptake of virus into cells, it may result in enhancement of the infection.
Thus, these antibodies are referred to as enhancing antibodies [18].

After a mosquito bite, dengue virus enters the skin and bind to the Langerhans cell membrane protein, DC-SIGN (Dendritic Cell-Specific Intercellular adhesion molecule-3-Grabbing Non-integrin), on the dendritic cells. Inside cells, the viral RNA starts replicating and release mature viruses. These viruses then continue to enter monocytes and macrophages [19].

The Dengue virus infections cause immune system activation and production of interferons via the JAK-STAT pathway. The antibodies produced against the virus help in phagocytosis of the virus and help virus particles to enter phagocytic cells and replicate further. 
The hemorrhagic disease of dengue is characterized by a vasculopathy and plasma leakage that may lead to shock and death. The exact cause of vasculopathy is not clear but it is associated with multiple factors like plasmablasts, complement and platelets. During the critical stage of infection, the virus specific plasmablasts expand to produce antibodies, and immune complexes that can activate complement and result in platelet depletion that is observed with dengue hemorrhagic fever. Platelet activation results in the release of vasoactive anaphylatoxins which lead to shock. Dengue virus is also known to enhance cytokine dependent (e.g. IL- 8) endothelial tight junction openings which contributes to increased vascular permeability. Activation of CD27+ and CD38+ plasmablasts can lead to a massive immune response after which, the soluble forms of these antigens increase in the plasma, as seen from cultures of purified polyclonally stimulated B cells. Therefore, plasma sCD27 (s: soluble) and sCD38 can be used as biomarkers that may be used to predict the clinical outcome of dengue infection [20]. Vascular leaks are due to sequestration of platelets in the micro circulation while elevation of IL-18 associated with dengue infections could result in thrombocytopenia, neutropenia and liver enzyme elevation causing hemorrhage [21]. Dengue exhibits an immunological phenomenon call "original antigenic sin” or Hoskins effect, which is observed with secondary dengue infections. This has implications on developing a successful Dengue vaccine which protects against all 4 antigenic types.

\section{Diagnostic testing}

The classic dengue fever also called "break-bone fever". It presents with a severe muscle and joint pains associated with an acute febrile illness, headache, retro-orbital pain and sometimes a rash [22]. Leukopenia, thrombocytopenia and elevated serum liver enzyme levels are the typical laboratory findings of dengue fever [23] With marked thrombocytopenia and increased vascular permeability, it can result in dengue hemorrhagic fever that can be associated with circulatory failure, shock and even death [24].

The confirmatory lab tests for dengue fever are: isolation of virus, dengue antibody rising levels in serum, and specific Dengue viral antigens or RNA in serum or tissue (WHO, 1998). Hemagglutination inhibition (HI) test, IgM capture enzyme linked immunosorbent assay (MAC-ELISA) and PCR also has been used [25-29].

\section{Clinical presentations in mother, fetus and neonate}

During pregnancy, the presentation of dengue viral infection can be confused with other obstetrics complications, such as HELLP syndrome (hemolysis, elevated liver enzyme and low platelet counts) and other hemorrhagic diseases [30].

There have been multiple case reports about the vertical transmission of dengue virus infection. In one study, a primigravida was diagnosed with dengue infection at 37 weeks of gestation. She underwent a cesarean section and a deeply meconium stained baby was delivered. Three days later she developed fever and respiratory distress. The platelet count of baby was very low $\left(40,000 / \mathrm{mm}^{3}\right)$ and both $\operatorname{IgG}$ and IgM anti-dengue antibodies were positive. The baby was treated successfully with platelet transfusion [31]. Similarly, neonatal dengue infection was described in a patient where the infection was diagnosed on the fifth day of birth and lasted for five days. The platelet count of the baby dropped to 15,000 and anti-dengue antibodies were positive. Liver function tests (AST and ALT) were elevated. The dengue hemorrhagic fever has also been reported transmitted during the perinatal period in a primigravida. She presented with fever, a low hemoglobin and a low platelet count. She delivered vaginally but the baby was meconium stained. Mother went into dengue shock syndrome on day 5 of delivery but recovered with treatment. Her laboratory results were consistent with a secondary dengue infection. The infant developed high grade fever with a convalescent rash on day 5 . Laboratory tests indicated that the infant had a primary dengue infection which was confirmed by the polymerase chain reaction test for dengue type-2. Baby recovered uneventfully [32]. Most pregnant women with Dengue infection get thrombocytopenia ranging from $10,000-80,000 / \mathrm{mm}^{3}$. They also present with elevated liver enzymes (AST, 770-15.523 unit/l, and ALT 689-760 unit/l.) and often the dengue shock syndrome. The mortality due to Dengue during pregnancy is yet to be documented. However, it is a recognized risk factor of severe postpartum hemorrhage and should be considered when presented with peri-partum fever [25,29,33]. Neonatal dengue infections, after vertical transmission during the perinatal period, presents with low grade fever and a fine maculopapular rash mostly located on face and neck. Sometimes a petechial rash may be seen on the leg and thighs $[28,29]$. In neonatal dengue infection, liver and spleen were enlarged (liver 0.5-2 CM and spleen 0.5 $\mathrm{cm}$ ) below the costal margin. The PTT can be prolonged and fibrinogen levels are low [25]. In one case study, a premature infant with dengue fever died and had cerebral bleeding [26]. Liver enzymes, AST and ALT were raised in neonates with Dengue fever [26].

Management of dengue infection during pregnancy is mostly conservative. The mode of delivery should be based on obstetric indications. Neonates of mothers with dengue infection should be kept under supervision for any clinical or subclinical infections [32].

A novel live attenuated vaccine for dengue (Dengvaxia) is approved in five countries, but not commercially available in the US yet [34].

\section{Zika virus}

\section{Epidemiology}

Zika virus was first isolated in 1947 from a rhesus monkey of the Zika forest in Uganda. The primary regions with local mosquito - borne transmission of Zika virus are Central and South America, Caribbean islands, south Asia and Africa. In the United States, an increased number of cases has been documented in Florida and Puerto Rico. Human to human transmission is primarily via mosquitoes but it can also be transmitted during sexual intercourse, using of blood products, organ transplantation, vertically from mother to fetus and during accidental laboratory exposure [35-37]. Two main types of mosquitoes that transmits the infection are the female Aedes aegypti and Aedes albopictus. Virus has been isolated from numerous other species of the Aedes mosquitoes.

Aedes mosquitoes acquires the virus after biting an infected person. In the mosquito the virus enters the salivary glands after replicating for 5 to 10 days in the epithelial cells of the midgut. When the mosquito bites a healthy person, the virus infects the epidermal keratinocytes, skin fibroblast and Langerhans cells. Zika antigens in contrast to other flavivirids can be found in the nuclei of infected cells [37,38]. From the skin, it spreads to blood stream and regional lymph nodes.

\section{Pathogenesis}

After the virus is transmitted across the placenta it kills the neural progenitor cells and interferes with their proliferation, differentiation and migration in the developing fetus [40]. Zika virus has been demonstrated in both neocortical and spinal neuroepithelial stem cells of virus infected microencephalic brains. The virus also infects glial 
cells, resulting in the destruction of mitosis, structural disorganization and cell death [41]. Zika infected human microencephalic fetuses were found to have Zika viral RNA. Tissue sections of the infected human forebrains had Zika envelop proteins (E). Infected brain showed disrupted morphology with numerous ventricular protrusions and decrease in the density of basal processes. Neuroepithelia Stem Cells, (NES cells) and radial glial cells (RGCs) showed increase expression of cell surface proteins, AXL and TYRO 3, which serve as cell entry receptors [42]. Infected cells did not show significant changes in the number of mitochondria, but their shape and localization appeared different. Studies show that, TANK-binding kinase 1 (TBK1), a cellular kinase that is required for innate immunity and cell proliferation are differentially distributed (relocalized around mitochondria from cytoplasm) within the cells infected with Zika virus. This altered distribution of TBK1 within the cell results in change of cell-cycle dynamics which may influence the development of microcephaly of Zika virus infected fetuses. TBK1 inhibitor, Amlexanox was shown to exacerbate cellular effects induced by Zika virus infection [41]. Overall, the effect of zika virus on human NES cells and RGCs is to inhibit mitosis and increase cell death. Molecular mechanisms of these effects are beginning to unveil. Two main features of the Zika virus, neutrophism and teratogenicity makes it unique among arboviruses which could result human diseases of epidemic proportions. Primary mechanism by which the virus produce disease is by preferentially infecting stem cells and suppressing their multiplication and death by non-immunological means. Fetal brain being immunologically immature', non-immunological mechanisms of disease pathogenesis such as mitotic impairment and subcellular reorganization of organelles could contribute to clinical features of the Zika virus disease. Like most other arboviruses, Zika virus usually cause a mild febrile illness in adults with a normal immune system.

\section{Clinical Presentations and diagnostic testing}

The pregnant women exposed to Zika virus can present with symptoms such as fever, rash, arthralgia and conjunctivitis. Rarely, adults may present with Guillain - Barre syndrome and meningoencephalitis. They carry the viral RNA, 10 weeks after the onset of symptoms in their serum which increase the risk of congenital infection even without symptoms [43,44].

The CDC recommends a diagnostic approach for women a) $<2$ or b) 2 to 12 weeks from the onset of symptoms or asymptomatic with possible Zika virus exposure, illustrated by an algorithm [44]. It has been shown that the vertical transmission is greatest during the first trimester.

Laboratory tests recommended by the CDC, include zika virus real time reverse-transcription polymerase chain reaction (RT- PCR), detection of Zika virus specific IgM and plaque reduction neutralization test.

\section{Fetal and neonatal presentations (The Zika syndrome)}

The common fetal anomalies in utero are the calcification (intracranial) $27 \%$, ventriculomegaly $33 \%$ and microcephaly $24 \%$ [46]. The key clinical finding is microcephaly with a congenital Zika syndrome early in pregnancy [47]. Other clinical features of congenital Zika syndrome include craniofacial disproportion in relation to microcephaly so the face appears large compared to head, Cutis girata (skin folds on scalp), ocular abnormalities (optic nerve abnormalities, microphthalmia, falciform folds, cataracts, retinal dysplasia, persistent fetal vasculature, nystagmus) [48], carniosyntesis (closed anterior fontanelle at birth) hypertonia/spasticity, hyperreflexia, seizures, irritability, arthrogryposis (arthrogryposis and club foot), ocular abnormalities, and sensorineural hearing loss with sever microcephaly and small for gestational age (40\%) of infants $[49,50]$.

\section{Japanese encephalitis virus (JEV)}

\section{Epidemiology}

JEV is the cause of the most frequent (about 68,000 cases/ year globally) and severe form of viral encephalitis and childhood neurological infections and disabilities [51].

Japanese encephalitis is endemic in the tropics especially when the weather is warm, humid and wet [52]. In endemic areas majority of the population can develop immunity following natural exposure to JEV [53].

JEV is a mosquito-borne flavivirus. JEV life cycle involves the Culex mosquitos and vertebrates (pigs) and birds as amplifying hosts, Humans are incidental and dead-end hosts in the JEV transmission cycle. The mosquitoes do not transmit JEV between humans because the viremia developed during an infection is insufficient for direct transmission. Therefore, they utilize pigs and ardeid birds which are the most important sources for amplifying the virus for human to human transmission to occur [15].

About 709,000 cases of Japanese encephalitis are estimated to occur globally each year (WHO Bulletin, 2011). It is one of the leading causes of adult and pediatric viral encephalitis, and childhood disability in Asia [51]. JEV typically affects children less than 15 years of age but travelers of any age can be affected. In sub-temperate climates (including China, Japan, South Korea, Nepal, northern Vietnam, and northern India), JEV cases occur during the season of heavy rainfall [54]. In tropical climates (including Cambodia, Indonesia, southern Vietnam, Sri Lanka and southern Thailand), the transmission occurs throughout the year, but it increases during rainy/monsoon seasons [54].

\section{Pathogenesis}

JEV consist of a single positive strand RNA genome surrounded by a nuclear capsid and a glycoprotein envelop. It encodes for a protein which is post-transationally modified to generate 3 structural proteins and seven non-structural proteins. The structural protein $\mathrm{E}$ is immunogenic and required to enter host cells by a mechanism of viral membrane fusion to the host endosomal membrane and releasing of the nucleoplasmid to the cytoplasm. Virus particles are taken up by Langerhans's cells of the skin and are transported to the regional lymph nodes. The primary immune response to the virus is usually abortive. Secondary viremia which results from infection of secondary lymphoid organs resulting in infections of organs such as kidney, liver, spleen and later the brain. The virus has the capacity to cross the blood-brain barrier directly or carried into the CNS via infected inflammatory cells, monocytes and macrophages or by crossing the endothelial lining of cerebral vessels. JEV can cause extensive brain damage resulting in neuronal loss primarily due to the secretion of pro-inflammatory cytokines and chemicals such as TNF- $\alpha$, IL-1, Rantes, MCP-1 and NO. JEV can invade the central nervous system and consequently induce neuroinflammation, which is characterized by profound neuronal cell damage accompanied by astrogliosis and microgliosis [55]. Experimentally when human glioma cells (U251) and mouse microglial cell lines (BV-2) are infected with the JEV, they produce significantly high amounts of proinflammatory cytokines. Interestingly, it's shown that an increase in proinflammatory cytokines is associated with over 
expression of the intermediate signaling protein, JNK 1 (jun n-terminal kinase 1). These studies indicate the importance of JNK 1 dependent signaling pathway in the pathogenesis of JEV induced inflammation in microglia and neuronal cells in mice [56].

Many vaccines are available to prevent of JEV infection. All of them are based on genotype III virus. These are: Live attenuated SA 1414-2 (in China), Inactivated vero-cell derived vaccines, IC51 and Live ChimeriVax - JE [57].

\section{Clinical presentation and diagnostic testing}

Acute encephalitis is the commonest clinical presentation of JEV infection. The milder forms can present as headache, aseptic meningitis and nonspecific febrile illness [51].

Initial symptoms include fever, diarrhea, and rigors that can be followed by headache, vomiting, and a generalized weakness. Over the next few days, the mental status might change, and patient may present with abnormal behavior or psychosis. Subtle motor seizures (usually generalized tonic-clonic) are very common among children who may present with twitching of a digit, eye deviation, or irregular breathing [58].

The laboratory diagnosis of JEV infection is by ELISA which can detect JEV specific IgM antibodies in serum or CSF during $3^{\text {rd }}$ to the $8^{\text {th }}$ day of infection. CSF antibodies are detectable five to eight days after the onset of symptoms in $70-90 \%$ of JEV patients. The antibodies in serum are detectable in about $60-70 \%$ of patients collected at least nine days after the onset of symptoms [59,60]. Sometimes, histopathology with immunohistochemistry and virus culture of autopsy tissues can also be used.

Definitive diagnosis is by virus isolation or detection of viral RNA with nucleic acid amplification tests [60].

\section{Clinical presentation in fetus and neonate}

JEV gestational infection in mice is primarily vertical. In pigs JEV infection during pregnancy could be asymptomatic but can result in abortions and stillbirths [58]. Reports on human studies are very limited.

Symptomatic disease is found in less than one percent of people which can lead to severe encephalitis with high mortality (25\%). Infected subjects have a spectrum of clinical disease ranging from fever and, headache, to more severe symptoms such as convulsions. Neurological symptoms include generalized or asymmetrical muscle weakness, flaccid or spastic paralysis and extrapyramidal signs. Severe cases may develop multiple seizures or status epilepticus, which are generally associated with a poor clinical outcome.

The illness acquired during the first and second trimester of pregnancy can infect the fetal and placental tissues resulting in abortion and stillbirths. Third trimester infections usually do not cause abortions. However, congenital infections have been reported in susceptible populations with little or no immunity.

The diagnosis of JEV infection during pregnancy is established on the basis of the clinical presentation, rising titers of hemagglutinationinhibiting antibody, and the presence of virus specific IgM antibodies. The first report of human vertical infection of JEV was presented in 1980 during a widespread epidemic. This report showed that the effects of JEV on fetuses of pregnant women could vary widely. Two infected women delivered normal neonates while two other women had abortions. The JEV was isolated from brain, liver and placental tissue of one of the aborted fetus [61].

\section{West nile virus (WNV)}

\section{Epidemiology}

WNV is one of the most widely distributed arboviruses across the globe. In 1999, it was detected in America, in the New York City, during an outbreak. WNV is distributed extensively in Africa, Middle East, Russia, South Asia, and Australia [13]. It is also endemic in North America [62].

WNV is transmitted to humans primarily through the bite of infected female Culex species of mosquitoes. It is a neurotropic flavivirus that is antigenically related to Japanese encephalitis (JEV) and St Louis encephalitis viruses. Since its discovery in the New York City in 1999 and since then about 6000 cases have been reported in the US $[63,64]$.

\section{Pathogenesis}

Virus deposited in the skin is taken up by dermal dendritic and Langerhans cells which are transported to the regional lymph nodes. Primary viremia results from replication in the regional lymph nodes which are then transported to the peripheral organs such as spleen and liver. Secondary viremia which result from replication in these organs are cleared by about day 6-8 to reach the brain and spinal cord by crossing the blood brain barrier. Like with most other neurotrophic viruses, WNV induce a pro-inflammatory cytokine response in the brain which is responsible for neuronal damage. Viral capsid proteins are responsible for apoptotic cell death contributing to the pathology of the disease. Cell culture studies show WNV associated upregulation of apoptotic cell death via increase expression of NF-kappa and TNF receptor associated factor 1 genes.

\section{Clinical presentation in adults and diagnostic testing}

The clinical presentation of WNV infection is usually characterized by an abrupt onset of fever, headache, malaise, back pain, myalgias, and anorexia. It can present as a self-limiting illness without fever [69]. Patient may present with eye pain, rash, pharyngitis and gastrointestinal tract symptoms (nausea, vomiting, diarrhea, and abdominal pain) [66]. The neuro-invasive disease with WNV can present as fever, meningitis, encephalitis or flaccid paralysis with mortality rate of $10 \%$ [67].

The diagnosis is confirmed by the WNV specific IgM antibodies in serum or CSF. The diagnostic test IgM - ELISA that is optimal for the detection WNV specific IgM which is simple and sensitive, for serum and CSF samples. The more specific antibody test is the Plaque Reduction Neutralization Test (PRNT). PRNT is not commercially available but can be performed at the CDC and some other US health department laboratories. Detection of virus is highly specific but has limited value for routine diagnosis because of the short-lived viremia [68].

\section{Fetal and neonatal syndrome}

The congenital WNV infection was described for the first time in 2002, with bilateral chorioretinitis and severe bilateral cerebral destruction [69]. A study of 77 women from 16 different states infected with WNV during pregnancy in 2003-2004 was published by the state health department. Among the 77 pregnant women infected with WNV, 4 women aborted spontaneously and 2 opted for elective abortion. Among the 72 live births, 54 newborns were found negative 
for anti-WNV IgM. The major malformations noted among the 7 liveborn infants were aortic coarctation, cleft palate, Down syndrome, microcephaly, and polydactyly. Abnormal growth was shown in 8 infants and one had a glycogen storage disease. Women were infected equally ( 33\%) during all 3 trimesters.

The anomaly rate was $10.6 \%$ which was above the rate for general population (5.5\%) suggesting that WNV infection may be a reason for congenital anomalies observed in these patients [70].

\section{Chikungunya virus (CHIKV)}

\section{Epidemiology}

Discovered in 1952 in east Africa, CHIKV moved to Asia and South America in the past few decades. It is an alpha virus that has reemerged unexpectedly, in the Indian subcontinent. It is endemic to Asia and Africa and is transmitted by many mosquito species including A. aegypti. There is a limited information about the pathogenesis of CHIKV [71]. It gives rise to a febrile flu like illness often associated with rash, and arthralgia. Thrombocytopenia associated with hemorrhage is rare although ocular complications with the meningo-encephalopathy could occur in children.

\section{Pathogenesis}

CHIKV is a single stranded positive sense RNA virus which undergo receptor (ICAM-3, CD209, CLEC4M) mediated endocytosis and release of nucleocapsid and viral genome into the cytoplasm. Genomic RNA undergoes replication via a negative RNA strand intermediate where nucleocapsid assembly and RNA packaging into budding virus particles takes place. These virions disseminate through blood into various organs such as brain heart kidney, liver and the muscular skeletal system [72]. Non-hemopoietic fibroblast are susceptible to the viral infection along with monocytes and macrophages which in turn are responsible for synthesis of pro-inflammatory cytokines such as IL1- $\beta$, IL- 6 , TNF- $\alpha$, which are the key pyrogens. These cytokines contribute to joint inflammation and tissue destruction which are predominant symptoms of the disease. A study done with patients infected with CHIKV had elevated levels of RANKL an osteoprotegerin (OPG) which is associated with high activity of macrophage derived osteoclasts. Osteoclast cause bone erosions leading to chronic bone and joint disease [73].

\section{Clinical presentations and diagnostic testing}

The virus enters and replicates in the skin through a mosquito bite and then disseminates hematogenously to organs such as liver, muscle, spleen, brain and joints. Virus transmission from mother to the child at birth was first identified in Feb 2006 [74,75]. Vertical transmission resulted in congenital malformations, still births and growth restrictions and preterm delivery [76]. Hyperpyrexia associated with this infection can result in fetal heart arrhythmias and stimulate spontaneous preterm delivery. Although uncommon, there are reports where hemorrhagic syndrome was manifested by excessive vaginal bleeding during delivery similar to dengue hemorrhagic fever [77,78]. A recent study which included 1400 pregnant women whose chikungunya infection was confirmed by specific serology or RT- PCR, 93\% of them were symptomatic during pregnancy. Overall the outcome of chikungunya infection during pregnancy has been reduced mean birth weight, still births and congenital malformations. The most common malformations observed were neural tube defects, cardiovascular defects, genito-urinary tract anomalies, musculoskeletal defects and rare chromosomal aberrations. ${ }^{79}$ Laboratory diagnosis of
CHIKV is by demonstrating the virus, viral nucleic acid, or CHIKV specific IgM and neutralizing antibodies. Viral cultures may be positive during early stage of illness. CHIKV, RNA can be identified from serum in the first week of the illness. Definitive diagnosis is made by comparing convalescent-phase samples with acute-phase sample tests.

\section{Yellow fever virus (YFV)}

\section{Epidemiology}

Approximately 200,000 cases occur annually [79], mainly in Africa where human populations is dense and immunization coverage is low (“urban yellow fever") [80,81].

\section{Pathogenesis}

YFV has a positive sense single stranded RNA genome, which produces 3 structural and seven non-structural proteins. Nonstructural protein $\mathrm{E}$ is responsible for attachment and internalization of the virus. Anti-E antibodies inhibits these functions. There are 7 major genotypes of yellow fever RNA virus [81,82]. After the virus is released from the mosquitoes into the skin, it enters regional lymph nodes where it multiplies and results in a primary viremia. In 24-hours the virus enters the liver and many other organs. Liver is the primary site of infection, results in mid-zonal hepatic injury where many hepatocytes will undergo apoptosis. This might explain the relative absence of an inflammatory response seen in specimens of the yellow fever liver. Most hepatocytes in the mid-zone carry viral RNA indicating differential infection of liver with the virus.

\section{Clinical presentation and diagnostic testing}

The clinical presentation is characterized by three phases of the infection where the first phase is, nonspecific symptoms and signs including fever, malaise, headache, joint pain, nausea, and vomiting. The second phase is remission period that can last up to 48 hours. The third phase of intoxication is characterized by hepatic dysfunction, renal failure, coagulopathy, and shock. During the first phase, the viremia gives symptoms, leukopenia and elevated serum transaminase level. Most patients recover and go into remission, however 15\% can enter the third phase of intoxication that may present as recurrent fever, vomiting, jaundice, and bleeding diathesis [79].

The diagnosis is accomplished by the ELISA assay for viral specific IgM and identification of viral genome by PCR and a neutralization test. The treatment of yellow fever consists primarily of supportive care. Prevention is achieved by the live attenuated vaccine (17D strain) that is used in endemic areas and in travelers. The vaccine produces immunity within 10 days, and revaccination is recommended every 10 years [82].

\section{Presentation in fetus and neonate}

In a study done in Brazil, maternal seroconversion was found to be very high during the first trimester of pregnancy after vaccination for yellow fever. The adverse prenatal effects found were similar to the general population [83].

\section{Conclusion}

Arboviral infections of pregnant women are considered to be the major cause of maternal, fetal and neonatal mortality and morbidity. These viruses infect mothers most commonly through mosquito bites and can infect fetuses/neonates through vertical transmission, vaginal blood and secretions and postnatally from breast milk [84]. The types of 
Table 1. Summary of common arboviruses causing pregnancy associated infections

\begin{tabular}{|c|c|c|c|c|c|}
\hline Virus & Pathogenesis / Vector & Maternal infection presentation/s & Diagnosis & Fetal / neonatal anomalies & Vaccines \\
\hline Dengue & $\begin{array}{l}\text { Vasculopathy due to complement } \\
\text { activation \& enhancing antibodies } \\
\text { followed by plasma leakage / Aedes } \\
\text { species of mosquitoes }\end{array}$ & $\begin{array}{l}\text { "Break-bone fever", } \\
\text { Dengue hemorrhagic fever (DHF) }\end{array}$ & $\begin{array}{l}\text { specific viral antigens or } \\
\text { RNA in serum or tissue }\end{array}$ & Fetal/neonatal hemorrhages & $\begin{array}{l}\text { Under review (will } \\
\text { be commercially } \\
\text { available soon) }\end{array}$ \\
\hline Zika & $\begin{array}{l}\text { Cell death and dys-mitosis of } \\
\text { neuroepithelial stem cells / Aedes } \\
\text { species of mosquitoes }\end{array}$ & $\begin{array}{l}\text { Fever, rash, arthralgia, conjunctivitis, } \\
\text { Guillain-Barre syndrome (rare) and } \\
\text { meningoencephalitis }\end{array}$ & $\begin{array}{l}\text { RT- PCR, specific IgM } \\
\text { and plaque reduction } \\
\text { neutralization test }\end{array}$ & $\begin{array}{l}\text { Microcephaly } 24 \% \text {, calcification } \\
\text { (intracranial) } 27 \% \text {, ventriculomegaly } \\
33 \%\end{array}$ & None \\
\hline $\begin{array}{l}\text { Japanese } \\
\text { encephalitis }\end{array}$ & $\begin{array}{l}\text { Cytokine driven neuroinflammation } \\
\text { and cell death /Culex species of } \\
\text { mosquitoes }\end{array}$ & $\begin{array}{l}\text { Acute encephalitis } \\
\text { (headache, aseptic meningitis and } \\
\text { nonspecific febrile illness } \\
\text { vomiting, and generalized weakness) }\end{array}$ & $\begin{array}{l}\text { IgM-ELISA and RT- } \\
\text { PCR for viral RNA }\end{array}$ & & $\begin{array}{l}\text { Live chimeric and } \\
\text { Inactivate vaccines } \\
\text { available }\end{array}$ \\
\hline West Nile & $\begin{array}{l}\text { Pro-inflammatory cytokine induced } \\
\text { apoptotic cell death of neurons / Culex } \\
\text { species of mosquitoes }\end{array}$ & $\begin{array}{l}\text { Fever, headache, malaise, back pain, } \\
\text { myalgia, and anorexia. } \\
\text { aseptic meningitis/ encephalitis } \\
\text { symptoms }\end{array}$ & $\begin{array}{l}\text { IgM-ELISA, } \\
\text { Plaque reduction } \\
\text { neutralization test, Virus } \\
\text { isolation PCR }\end{array}$ & $\begin{array}{l}\text { Congenital malformations, } \\
\text { (microcephaly, polydactyly, } \\
\text { chorioretinitis etc., and growth } \\
\text { retardation of infants }\end{array}$ & None \\
\hline Rift valley fever & $\begin{array}{l}\text { NSs proteins induced IFN- } \beta \text { inhibition } \\
\text { and apoptosis of host cells / Aedes and } \\
\text { Culex species of mosquitoes }\end{array}$ & $\begin{array}{l}\text { Fever, joint pain, rash and } \\
\text { hepatic dysfunction, meningitis/ } \\
\text { meningoencephalitis, hemorrhage }\end{array}$ & $\begin{array}{l}\text { IgM-ELISA, antigen } \\
\text { detection ELISA and } \\
\text { PCR }\end{array}$ & $\begin{array}{l}\text { Abortions, rash, hepato-splenomegaly } \\
\text { with ALT/AST elevation, bleeding } \\
\text { diathesis }\end{array}$ & None \\
\hline Chikungunya & $\begin{array}{l}\text { Pro-inflammatory cytokine induced } \\
\text { joint and tissue damage, high number } \\
\text { of osteoclasts induced bone erosion / } \\
\text { Aedes species of mosquitoes }\end{array}$ & $\begin{array}{l}\text { Fever, headache, rash and photophobia, } \\
\text { bone density changes and chronic bone } \\
\text { and joint disease }\end{array}$ & $\begin{array}{l}\text { IgM/IgG-ELISA, RT- } \\
\text { PCR }\end{array}$ & $\begin{array}{l}\text { Congenital malformations, still births, } \\
\text { uterine growth retardation, fetal heart } \\
\text { defects }\end{array}$ & None \\
\hline Yellow fever & $\begin{array}{l}\text { Apoptosis of hepatocytes (mid-zonal) / } \\
\text { Aedes species of mosquitoes }\end{array}$ & $\begin{array}{l}\text { Fever, headache, joint pain, vomiting, } \\
\text { hepatic dysfunction (icterus), renal } \\
\text { failure, coagulopathy, and shock. }\end{array}$ & $\begin{array}{l}\text { IgM-ELISA, PCR for } \\
\text { viral RNA }\end{array}$ & Inconclusive data & $\begin{array}{l}\text { Live attenuated } \\
\text { vaccines for } \\
\text { travelers to Africa } \\
\text { and S. America }\end{array}$ \\
\hline
\end{tabular}

viral agent, gestational age at exposure and immunological immaturity of the fetus determines the clinical manifestations of mother and her newborn infant. There is a compelling evidence that some of the arboviruses result in fetal abortion and congenital anomalies. World wide data shows that 402,000 out of 2.68 million neonatal deaths /year are due to the congenital anomalies. The arboviral infections sometimes can result in sever disease as illustrated in table 1. Many arboviruses have changed infection dynamics due to factors such as demographic changes, population growth, international travel, vector dynamics, nutritional factors, climate changes and mutations of the viruses. Direct viral effects (e.g. apoptotic cell death, rate of cell multiplication) on the developing embryo/fetus could result in developmental anomalies and growth retardation. The most commonly used methods of perinatal diagnosis of arboviral infections are by detection of viral specific - antigens, - IgM/IgG and - RNA. There are a few vaccines available (Yellow fever, JEV) that can be safely used in pregnancy. Prevention is the key for controlling arboviral disease.

\section{References}

1. CDC Information on Arboviral Encephalitides. Archived from the original on January 27, 2007. Retrieved 2007-02-07.

2. Chaves-Carballo E (2005) Carlos Finlay and yellow fever: Triumph over adversity. Military medicine 170: 881-885. [Crossref]

3. Russell FF (1934) Permanent Value of Major Walter Reed's Work on Yellow Fever. Am J Public Health Nations Health 24: 1-10. [Crossref]

4. Henchal EA, Putnak JR (1990) The dengue viruses. Clin Microbiol Rev 3: 376-396. [Crossref]

5. Last J (2001) A Dictionary of Epidemiology. New York, Oxford University Press: 9780-19-514169-6.

6. Depaquit J, Grandadam M, Fouque F, Andry PE, Peyrefitte C (2010) Arthropod-borne viruses transmitted by Phlebotomine sandflies in Europe: A review. Euro Surveill 15: 19507. [Crossref]

7. Cerino A, Bissolati M, Cividini A, Nicosia A, Esumi M, et al. (1997) Antibody responses to the hepatitis $\mathrm{C}$ virus $\mathrm{E} 2$ protein: relationship to viraemia and prevalence in anti-HCV seronegative subjects. J Med Virol 51: 1-5. [Crossref]

8. Weaver SC (2005) Host range, amplification and arboviral disease emergence. Arch Virol Suppl 19: 33-44. [Crossref]
9. Bowen RA, Nemeth NM (2005) Experimental infections with West Nile virus. Cur Opin Infect Dis 20: 293-297. [Crossref]

10. Bhatt S, Gething PW, Brady OJ, Messina JP, Farlow AW, et al. (2013) The global distribution and burden of dengue. Nature 496: 504-507. [Crossref]

11. Nobuchi H (2010) The symptoms of a dengue-like illness recorded in a Chinese medical encyclopedia. Kanpo Rinsho 26: 422-425.

12. Kuno G (1995) Review of the factors modulating dengue transmission. Epidemiol Rev 17: 321-335. [Crossref]

13. Gubler DJ (2007) The continuing spread of West Nile virus in the western hemisphere Cline Infect Dis 45:1039-1046. [Crossref]

14. Vaughn DW, Green S, Kalayanarooj S, Innis BL, Nimmannitya S, et al. (1997) Dengue in the early febrile phase: viremia and antibody responses. J Infect Dis 176: 322-330. [Crossref]

15. Endy TP, Nisalak A, Chunsuttiwat S, Libraty DH, Green S, et al. (2002) Spatial and temporal circulation of dengue virus serotypes: a prospective study of primary schoo children in Kamphaeng Phet, Thailand. Am J Epidemiol 156: 52-59. [Crossref]

16. Nguyet MN, Duong TH, Trung VT, Nguyen TH, Tran CN, et al. (2013) Host and viral features of human dengue cases shape the population of infected and infectious Aedes aegypti mosquitoes. Proc Natl Acad Sci U S A 110: 9072-9077. [Crossref]

17. Schmid MA, Glasner DR, Shah S, Michlmayr D, Kramer LD, et al. (2016). Mosquito Saliva Increases Endothelial Permeability in the Skin, Immune Cell Migration, and Dengue Pathogenesis during Antibody-Dependent Enhancement. PLoS Pathog 12: e1005676. [Crossref]

18. Martina BE, Koraka P, Osterhaus AD (2009) Dengue virus pathogenesis: an integrated view. Clin Microbiol 22: 564-581. [Crossref]

19. Castañeda DM, Salgado DM, Narváez CF (2016) B cells naturally induced during dengue virus infection release soluble CD27, the plasma level of which is associated with severe forms of pediatric dengue. Virology 497: 136-145. [Crossref]

20. Nascimento EJ, Hottz ED, Garcia-Bates TM, Bozza F, Marques ET, et al. (2014) Emerging concepts in dengue pathogenesis: interplay between plasmablasts, platelets, and complement in triggering vasculopathy. Crit Rev Immunol 34: 227-240. [Crossref]

21. Rigau-Pérez JG (1998) The early use of break-bone fever (Quebranta huesos, 1771) and dengue (1801) in Spanish. Am J Trop Med Hyg 59: 272-274. [Crossref]

22. Schwartz E, Mendelson E, Sidi Y (1996) Dengue fever among travelers. Am J Med 101: 516-520. [Crossref]

23. Kalayanarooj S, Vaughn DW, Nimmannitya S, Green S, Suntayakorn S, et al. (1997) Early clinical and laboratory indicators of acute dengue illness. J Infect Dis 176: 313321. [Crossref] 
24. Thaithumyanon P, Thisyakorn U, Deerojnawong J, Innis BL (1994) Dengue infection complicated by severe hemorrhage and vertical transmission in a parturient woman. Clin Infect Dis 18: 248-249. [Crossref]

25. Chy JK, Lim CT, Ng KB, Lim JMH, George R, et al. (1997) Vertical transmission of dengue. Clin Infect Dis 25: 1374-1377. [Crossref]

26. Boussemart T, Babe P, Sibille G, Neyret C, Berchel C (2001) Prenatal transmission of dengue: two new cases. $J$ Perinatol 21: 255-257. [Crossref]

27. Kerdpanich A, Watanaveeradej V, Samakoses R, Chumnanvanakij S, Chulyamitporn T, et al. (2001) Perinatal dengue infection. Southeast Asian J Trop Med Public Health 32: 488-493. [Crossref]

28. Petdachai W, Sila'an J, Nisalak A. Nimmanitya S (2004) Neonatal dengue infection: report of dengue fever in a 1-day-old infant. Southeast Asian J Trop Med Public Health 35: 403-407. [Crossref]

29. Vorapong P (2001) Dengue fever in pregnancy: a case report. BMC Pregnancy Childbirth 1: 7. [Crossref]

30. Fatimil LE, Mollah AH, Ahmed S, Rahman M (2003) Vertical transmission of dengue: first case report from Bangladesh. Southeast Asian J Trop Med Public Health 34: 800803. [Crossref]

31. Janjindamai W, Pruekprasert P (2003) Perinatal dengue infection: a case report and review of literature. Southeast Asian J Trop Med Public Health 4: 793-796. [Crossref]

32. Chotigeat U, Khaoluang S, Kanjanapatanakul V, Nisalak A (2000) Vertical transmission of dengue virus. J Infect Dis Antimicrob Agents 17: 33-35.

33. Maron, Dina "First Dengue Fever Vaccine Gets Green Light in 3 Countries". Scientific American. Retrieved 3 February 2016. Available at: https://www.scientificamerican. com/article/first-dengue-fever-vaccine-gets-green-light-in-3-countries/.

34. Musso D, Nhan T, Robin E, Roche C, Bierlaire D, et al. (2014) Potential for Zika virus transmission through blood transfusion demonstrated during an outbreak in French Polynesia, 2014. Euro Surveill 19: pii: 20761. [Crossref]

35. Centers for Disease Control and Prevention. CDC encourages following guidance to prevent sexual transmission of Zika virus. Available at: http://www.cdc.gov/media/ releases/2016/s0223-zika-guidance.html

36. Motta IJ, Spencer BR, Cordeiro da Silva SG, Arruda MB, Dobbin JA, et al. (2016) Evidence for Transmission of Zika Virus by Platelet Transfusion. $N$ Engl J Med 375: 1101-1103. [Crossref]

37. Buckley A, Gould EA (1988) Detection of Virus-specific Antigen in the Nuclei or Nucleoli of Cells Infected with Zika or Langat Virus. J Gen Virol 69: 1913-1920. [Crossref]

38. Růzek D, Salát J, Palus M, Gritsun TS, Gould EA et al. (2009) CD8+ T-cells mediate immunopathology in tick-borne encephalitis. Virology 1: 1-6. [Crossref]

39. Costello A, Dua T, Duran P, Gülmezoglu M, Oladapo OT, et al. (2016) Defining the syndrome associated with congenital Zika virus infection. Bull World Health Organ 94: 406-406A. [Crossref]

40. Onorati M, Li Z, Liu F, Sousa AMM, Nakagawa N, et al. (2016) Zika virus disrupts phosphor-TBK1 localization and mitosis in human neuroepithelial stem cells and radial glia. Cell Reports 16: 2576-2592. [Crossref]

41. Hamel R, Dejarnac O, Wichit S, Ekchariyawat P, Neyret A, et al. (2015) Biology of Zika Virus Infection in Human Skin Cells. J Virol 89: 8880-8896. [Crossref]

42. Driggers RW, Ho CY, Korhonen EM, Kuivanen S, Jääskeläinen AJ, et al. (2016) Zika Virus Infection with Prolonged Maternal Viremia and Fetal Brain Abnormalities. $N$ Engl J Med 374: 2142-2451. [Crossref]

43. Meaney-Delman D, Oduyebo T, Polen KN, White JL, Bingham AM, et al. (2016) Zika Pregnancy Registry Prolonged Viremia Working Group, Prolonged Detection of Zika Virus RNA in Pregnant Women. Obstet Gynecol 128: 724-730. [Crossref]

44. Practice Advisory on Zika Virus, American College of Obstetrician and Gynecologist, women health care physicians. Available at: https://www.acog.org/Clinical-Guidanceand-Publications/Practice-Advisories/Practice-Advisory-Interim-Guidance-for-Careof-Obstetric-Patients-During-a-Zika-Virus-Outbreak?IsMobileSet=false

45. Vouga M, Baud D (2016) Imaging of congenital Zika virus infection: the route to identification of prognostic factors. Prenat Diagn 36: 799. [Crossref]

46. Brasil P, Pereira JP, Raja Gabaglia C, Damasceno L, Wakimoto M, et al. (2016) Zika Virus Infection in Pregnant Women in Rio de Janeiro. N Engl J Med 375: 2321-2334. [Crossref]
47. Schuler-Faccini L, Ribeiro EM, Feitosa IM, Horovitz DD, Cavalcanti DP, et al (2016) Brazilian Medical Genetics Society-Zika Embryopathy Task Force, Possible Association Between Zika Virus Infection and Microcephaly - Brazil, 2015. MMWR Morb Mortal Wkly Rep 65: 59-62. [Crossref]

48. Leal MC, Muniz LF, Ferreira TS, Santos CM, Almeida LC, et al. (2016) Hearing Loss in Infants with Microcephaly and Evidence of Congenital Zika Virus Infection - Brazil, November 2015-May 2016. MMWR Morb Mortal Wkly Rep 65 :917-919. [Crossref]

49. de Fatima Vasco Aragao M, van der Linden V, Brainer-Lima AM, Coeli RR, Rocha MA, et al. (2016) Clinical features and neuroimaging (CT and MRI) findings in presumed Zika virus related congenital infection and microcephaly: retrospective case series study. BMJ 353: i1901. [Crossref]

50. Halstead SB, Jacobson J (2003) Japanese encephalitis. Adv Virus Res 61: 103-138. [Crossref]

51. Arai S, Matsunaga Y, Takasaki T, Tanaka-Taya K, Taniguchi K, et al. (2008) Vaccine Preventable Diseases Surveillance Program of Japan, Japanese encephalitis: surveillance and elimination effort in Japan from 1982 to 2004. Jpn J Infect Dis 61: 333

52. Tsai TF (2006) Congenital Arboviral Infections: Something New, Something Old Pediatrics 117: 936-939. [Crossref]

53. Mackenzie JS, Williams DT, Smith DW (2006) Japanese encephalitis virus: The geographic distribution, incidence, and spread of a virus with a propensity to emerge in new areas. Elsevier 16: 201-268.

54. Ompusunggu S, Hills SL, Maha MS, Moniaga VA, Susilarini NK, et al. (2008) Confirmation of Japanese encephalitis as an endemic human disease through sentine surveillance in Indonesia. Am J Trop Med Hyg 79: 963-970. [Crossref]

55. Jing Ye, Hao Zhang, Wen He, Bibo Zhu, Dengyuan Zhou, et al. (2016) Quantitative phosphoprotenemic analysis identifies the critical role of JNK1 in neuroinflammation induced by the Japnese encephalitis virus. Sci Signal 9: 98. [Crossref]

56. Schiøler KL, Samuel M, Wai KL (2007) Vaccines for preventing Japanese encephalitis. Cochrane Database Syst Rev 3: CD004263. [Crossref]

57. Halstead SB, Jacobson J (2003) Japanese encephalitis. Adv Virus Res 61: 103-138. [Crossref]

58. Solomon T, Dung NM, Kneen R, Thao le TT, Gainsborough M, et al. (2002) Seizures and raised intracranial pressure in Vietnamese patients with Japanese encephalitis. Brain 125: 1084-1093. [Crossref]

59. Mammen MP, Clemens JD, Nisalak A, Subrata K, Kim HK, et al. (2006), A hospitalbased surveillance for Japanese encephalitis in Bali, Indonesia. BMC Med 4: 8 . [Crossref]

60. Chaturvedi UC, Mathur A, Chandra A, Das SK, Tandon HO, et al. (1980) Transplacental infection with Japanese encephalitis virus. J Infect Dis 141: 712-715. [Crossref]

61. Brown CM, De Maria AU (2012) The resurgence of West Nile virus. Ann Intern Med 157: 823-824. [Crossref]

62. Nash D, Mostashari F, Fine A, Miller J, O'Leary D, et al. (2001) The outbreak of Wes Nile virus infection in the New York City area in 1999. N Engl J Med 344: 1807-1814. [Crossref]

63. Hayes EB, Komar N, Nasci RS, Montgomery SP, O'Leary DR, et al. (2005) Epidemiology and dynamics of transmission of West Nile virus disease. Emerg Infect Dis 11: 1167-1173. [Crossref]

64. Orton SL, Stramer SL, Dodd RY (2006) Self-reported symptoms associated with West Nile virus infection in RNA-positive blood donors. Transfusion 46: 272-277. [Crossref]

65. Zou S, Foster GA, Dodd RY, Petersen LR, Stramer SL (2010) West Nile fever characteristics among viremic persons identified through blood donor screening. $J$ Infect Dis 202: 1354-1361. [Crossref]

66. Davis LE, DeBiasi R, Goade DE, Haaland KY, Harrington JA, et al. (2006) West Nile virus neuroinvasive disease. Ann Neurol 60: 286-300. [Crossref]

67. Busch MP, Kleinman SH, Tobler LH, Kamel HT, Norris PJ, et al. (2008) Virus and antibody dynamics in acute west nile virus infection. J Infect Dis 198: 984-993. [Crossref]

68. Alpert SG, Fergerson J, Noel LP (2003) Intrauterine West Nile virus: ocular and systemic findings. Am J Ophthalmol 136: 733-735. [Crossref]

69. O'Leary DR, Kuhn S, Kniss KL, Hinckley AF, Rasmussen SA, et al. (2006) Birth outcomes following West Nile virus infection of pregnant women in the United States, 2003-2004. Pediatrics 117: 537-545. [Crossref] 
70. Schwartz O, Albert ML (2010) Biology and pathogenesis of chikungunya virus, signs in fetus and neonate. Nat Rev Microbiol 8: 491-500. [Crossref]

71. Kam YW, Ong EK, Rénia L, Tong JC, Ng LF (2009) Immune-biology of chikungunya and implications for disease interventions. Microbes Infect 11: 1186-1196. [Crossref]

72. Chen W, Foo SS, Rulli NE, Taylor A, Sheng KC, et al. (2014) Arthritogenic Alphaviral Infection Perturbs Osteoblast Function and Triggers Pathologic Bone Loss. Proc Natl Acad Sci U S A 111: 6040-6045. [Crossref]

73. Robillard PY, Boumahni B, Gérardin P, Michault A, Fourmaintraux, A, et al. (2006) Vertical maternal fetal transmission of the chikungunya virus. Ten cases among 84 pregnant women [in French]. Presse Med 35: 785-758. [Crossref]

74. Ramful D, Carbonnier M, Pasquet M, Bouhmani B, Ghazouani J, et al. (2007) Mother-tochild transmission of chikungunya virus infection. Pediatr Infect Dis J 26: 811-815. [Crossref]

75. Andrade JQ, Bunduki V, Curti SP, Figueiredo CA, de Oliveira MI, et al. (2006) Rubella in pregnancy: intrauterine transmission, and perinatal outcome during a Brazilian epidemic. J Clin Virol 35: 285-291. [Crossref]

76. Carles G, Talarmin A, Peneau C, Bertsch M (2000) Dengue fever and pregnancy. A study of 38 cases in French Guiana [in French]. J Gynecol Obstet Biol Reprod 29: 758-762. [Crossref]

77. Waduge R, Malavige GN, Pradeepan M, Wijeyaratne CN, Fernando S, et al. (2006) Dengue infections during pregnancy: a case series from Sri Lanka and review of the literature. J Clin Virol 37: 27-33. [Crossref]
78. Fritel X, Rollot O, Gerardin P, Gauzere BA, Bideault J, et al. (2010) Chikungunya Virus Infection during Pregnancy, Réunion, France, 2006. Emerg Infect Dis 16: 418 425. [Crossref]

79. Robertson SE, Hull BP, Tomori O, Bele O, LeDuc JW, et al. (1996) Yellow fever: a decade of reemergence. JAMA 276: 1157-1162. [Crossref]

80. Mutebi JP, Wang H, Li L, Bryant JE, Barrett AD (2001) Phylogenetic and evolutionary relationships among yellow fever virus isolates in Africa. J Virol 75: 6999-7008. [Crossref]

81. Vasconcelos PF, Bryant JE, da Rosa TP, Robert BT, Sueli GR, et al. (2004) Genetic divergence and dispersal of yellow fever virus, Brazil. Emerg Infect Dis 10: 1578-1584 [Crossref]

82. Thomas PM (2005) Treatment of yellow fever. Science Direct 78: 21-23.

83. Suzano CE, Amaral E, Sato HK, Papaiordanou PM; Campinas Group on Yellow Fever Immunization during Pregnancy (2006) The effects of yellow fever immunization (17DD) inadvertently used in early pregnancy during a mass campaign in Brazil Vaccine 24: 1421-1426. [Crossref]

84. Barthel A, Gourinat A, Cazorla C, Joubert C, Dupont-Rouzeyrol M, et al. (2013) Breast Milk as a Possible Route of Vertical Transmission of Dengue Virus? Clin Infect Dis 57: 415-417. [Crossref]

Copyright: (C2018 Nausheen F. This is an open-access article distributed under the terms of the Creative Commons Attribution License, which permits unrestricted use, distribution, and reproduction in any medium, provided the original author and source are credited. 